\title{
Does the Early Bird Catch the Worm or a Lower GPA? Evidence from a Liberal Arts College
}

Timothy M. Diette

\author{
Redenbaugh Term Associate Professor of Economics \\ Williams School of Commerce, Economics, and Politics \\ Huntley Hall, Room 302 \\ Washington and Lee University \\ 204 W. Washington St. \\ Lexington, VA 24450 \\ DietteT@wlu.edu
}

\author{
Manu Raghav \\ 202 Harrison Hall \\ DePauw University \\ 7 East Larabee Street \\ Greencastle, IN 46135 \\ manuraghav@depauw.edu
}

\section{This Version: March 9, 2016}

\section{DePauw University Economics Working Papers Series, 2016-01}

\begin{abstract}
Colleges and universities with capacity constraints like to offer early morning classes to maximize the use of classrooms. Moreover, evenings are often reserved for extra-curricular activities. However, research from psychology has shown that a teenager's mind benefits from additional sleep during early morning hours. We use data from a selective liberal arts college that assigns students randomly to different sections of the same course. This creates a natural experiment. Our paper shows that after controlling for other factors, students in early morning sections earn lower grades than students in sections of the same course offered later in the day. The result holds for all the courses offered at this institution. Grades are especially low for 8 am and 9 am classes for both genders, although the effect is larger for male students. This suggests that trade-offs exist between optimal use of classroom space and learning outcomes for students.
\end{abstract}

JEL CODES: I20, I21, I23, A22, Z18

KEYWORDS: Class time; grades; GPA; student learning 


\section{Introduction and Background}

Colleges and universities have several objectives when scheduling class times. The schools need to spread the classes across the day in order to make the most of the limited number of classrooms and faculty who teach multiple courses. In addition, they want to minimize the number of conflicts students have when creating their academic schedule each semester. Faculty members also have some input into the times when their courses are scheduled. As a result, classes are commonly scheduled starting at 8:00 am. Research and evidence from sleep literature suggests that the distinct circadian rhythm among adolescents makes early morning hours a difficult time to focus on academic tasks. ${ }^{1}$ In addition, research from psychology has documented a negative association between early morning courses and student learning (Wolfson and Carskadon 2003).

In the middle school and high school setting, Edwards (2012) exploits staggered start times, which resulted from a policy to reduce busing costs in the Wake County public schools, to estimate the effect of daily start time on academic performance. He finds gains in math test scores in the later classes, with the largest effect on students in the bottom end of the distribution. Other studies find that starting the school day as little as 20 minutes later have positive effects (Perkinson-Gloor et al., 2013). Cortes et al. (2010) exploit variation in assignment to first year classes in Chicago Public High Schools and find having a class in the first period lowers grades and, in the case of math courses, has a negative externality on related subjects. While evidence from a study of 144 medical students found a relationship between poor sleep quality and exam performance (Ahrber et al. 2012).

\footnotetext{
${ }^{1}$ For a review of the sleep literature see the discussion in Carrell et al. (2011).
} 
This paper extends the small existing literature on class time and academic achievement in colleges and universities in the United States. Dills and Hernandez (2008) examine the effect of the start time at Clemson University, a large public university. They use student and course fixed effects and find a positive association between later class times and student grades. Carrell, Maghakian, and West (2011) explore the influence of start time on freshman students at the United States Air Force Academy, an institution that has class sizes similar to liberal arts colleges. Exploiting variation across cohorts from a policy change in the start time of class periods as well as random assignment to courses and instructors-including not having a class in the first class period, they also find positive effects on student achievement from delaying the start of the school day by 50 minutes. One particular challenge of generalizing these results to other settings is that all of the students at the United States Air Force Academy are required to wake up at a common time for breakfast—although the breakfast time varies by up to 50 minutes due to policy changes. Therefore, one of the potential channels for benefits of later class starts times, students choosing to sleep later, is unavailable to these students. In addition, the entirety of their day is carefully planned out for them in a regimented lifestyle, a distinct experience relative to the more typical college student.

We contribute to the literature in several ways. This study examines a traditional liberal arts college, where students are not required to wake up at a particular time. This compliments the existing research on the large, public university and the military academy. In addition, while the students have more flexibility than the military academy, they are only able to sign up for courses, but not specific sections of the courses with multiple sections. Therefore, students are 
randomly assigned to starting times of a course as well as to professors in classes that offer multiple sections. This study also includes the entire student body, not only the students in their freshman year. Finally, we are the first to examine whether heterogeneous effects of early morning classes exist by gender.

\section{Data, Model, and Descriptive Statistics}

We obtained data from a private highly selective liberal arts college. ${ }^{2}$ The data include all student level individual course section grades at the institution for a nine year period covering the academic years of 1999-2000 through 2007-2008. The data capture student characteristics such as age, gender, academic standing, and SAT scores. In addition, for each course section we can identify characteristics such as the name of the instructor, the semester, the year, the number of students receiving grades in the individual sections, and the time of the course meetings. In order to study the influence of the starting time of a class on the grade that the student receives, we estimate the regression equation represented by equation (1).

$$
\begin{aligned}
& \text { Grade }_{\text {isdft }}=\alpha_{1}+\beta_{1}{\text { Class } \text { Time }_{s d f t}+B_{2} X_{i}+\beta_{3} \text { Section }_{\text {sdft }}}^{+\gamma_{d}+\varphi_{f}+\rho_{t}+\xi_{s}+\mu_{i s d f t}}
\end{aligned}
$$

We estimate variations of the model specified in equation (1) for the grade earned in a class by individual $i$ in section $s$ in department $d$ with faculty member $f$ in term $t$. Class Time indicates the hour of the beginning of the scheduled meetings for the course sections. $\beta_{1}$, the vector of coefficients corresponding to different hours in the day, represents our primary coefficients of

\footnotetext{
${ }^{2}$ The data was obtained under an agreement to not disclose the name of the institution.
} 
interest. In addition, $X$ represents a vector of student characteristics including gender, SAT Math and Verbal scores, and their class standing when enrolled in the course section. Section is a vector of course section characteristics other than the class time.

Following the literature, we include the class size as a determinant of a person's grade in a course (for example, see Diette and Raghav 2015). We also include the semester of the course and the level of course. The school operates on a three semester system with two traditional 12 week semesters as well as a short semester. Courses at the university are divided into 100-level introductory courses, 200-level intermediate courses, 300-level advanced courses, and 400-level courses. The latter typically involve independent student research and most 400 -level courses do not report the specific class meetings times. Therefore, we exclude the 400-level courses from our study.

In all specifications we include year fixed effects, $\rho_{t}$. Year fixed effects are added to control for any year specific trend in grades such as grade inflation over time. In some specifications, we also control for department fixed effects, $\gamma_{d}$. Different departments may have different grading norms. Furthermore, these standards may be used to manage demand for the courses and major. Also, the subjective versus objective nature of the material covered across different disciplines is associated with higher grades for relatively more subjective course content (Achen and Courant, 2009). Finally, we expect that faculty have unique characteristics and that they systematically give higher or lower grades relative to other instructors. Therefore, we include faculty fixed effects, $\varphi_{f}$. Finally, to control for unobserved individual characteristics such as motivation or preparedness, we include student fixed effects, $\xi$ s. 
Table 1 shows summary statistics of student and section quantitative variables. The mean number of the grade points earned in our sample is 3.22 on a 4.33 scale (an A+ counts 4.33 grade points). The relatively high average is consistent with grades at highly selective colleges. The median grade is a $\mathrm{B}+$ and the grade at the $25^{\text {th }}$ percentile is a B. Similarly, SAT scores reflect the selective natures of the school with means of 676 for SAT Math and 674 for SAT verbal scores. The mean class size is 21.2 students. This is again typical for a small liberal arts college, which emphasizes close interaction between faculty and students.

\section{< IINSERT TABLE 1 HERE〉>}

Table 2 shows summary statistics of the categorical variables used in the estimation. About 55 percent of students are male. There are slightly more students classified as first-year or sophomore students than upper-level students. While there is a very high retention rate, some students choose to transfer or otherwise remove themselves from the school. In addition, juniors and seniors are much more likely to spend a semester or full-year studying abroad. Finally, juniors and seniors are the primary students who enroll in the independent study 400-level courses that we have eliminated from our study. Most of the courses are 100-level courses followed by 200 -level courses. 10 am is the most popular starting time for a course section, while 8 am and 9 am are least prevalent among the morning class times. Very few classes are scheduled at $4 \mathrm{pm}$ or $5 \mathrm{pm}$ as the school tries to reserve these time slots for athletic practices and other student activities and the university does not offer courses in the evening or on weekends. 


\section{$<<$ INSERT TABLE 2 HERE $>$}

\section{Results}

We begin the analysis by examining the relationship between grade points earned and the class starting time for all 115,610 observations in our data. We estimate three specifications of equation (1) and report the estimated coefficients in Table 3. Year-fixed effects are included in all three specifications and $1 \mathrm{pm}$ serves as the reference class time. The column (1) regression results include controls for department fixed effects, but not faculty fixed effects. The column (2) regression controls for faculty fixed effects, but not department fixed effects. And the column (3) regression controls for both department and faculty fixed effects.

All of the morning classes are associated with lower grades relative to the $1 \mathrm{pm}$ time slot. All afternoon times are associated with higher grades, with the exception of the $3 \mathrm{pm}$ slot in column (3) - which is statistically the same at the $1 \mathrm{pm}$ time. The addition of faculty fixed effects, controlling for different grading standards by professor, in column (2) lowers the estimated magnitude of the effects in the early morning classes by 25 to 38 percent. The inclusion of the department fixed effects_-column (3) relative to column (2)—does not significantly change the estimated coefficients. The coefficients on the controls in the fully specified model all match the expected sign based on previous research. Male students and larger class sizes are associated with modestly lower grades. Students with advanced academic standing, higher SAT scores, and students in advanced courses all receive higher grades.

\section{< <INSERT TABLE 3 HERE〉>}


If students select courses based on the course meeting time then the results in Table 3 may be biased. The bias would be expected to bias the estimated effects toward zero as students who have private information that they will benefit from a later class meeting will self-select into these classes (and drop classes that meet in the early morning). The students we observe in the early morning classes would be students who are choosing to be there. To reduce this potential bias, we next estimate the effect of class meeting time on grades using the subset of courses that have multiple sections. As mentioned earlier, the students sign up for the course, but they are assigned to specific section and meeting time. Roughly half of the sample, 58,089 observations, come from courses with multiple sections. Table 4 presents the results and the specifications for each column match the order presented in Table 3. Examining Column (3), we see that the estimated coefficient on 8am is somewhat larger in absolute value than the estimate from column (3) in Table 3, -0.084 versus -0.061 . The other time slots have similar results to the estimates reported in Table 3 .

\section{$<<$ INSERT TABLE 4 HERE >>}

The previous results all document that female students outperform their male counterparts. Female students may be better at time management or more dedicated to their studies, but we are unable to identify the mechanism in this study. The effects of early morning classes may differ between male and female students. In Table 5, we report the estimated coefficients when we stratify the data by gender. Table 5 contains three separate regressions each for both male and 
female students. Again $1 \mathrm{pm}$ is the baseline class time category, as in Table 3. Column 3 and Column 6 regressions control for faculty, department, and year fixed effects. Both genders earn lower grades in morning classes and higher grades in afternoon classes. Comparing columns (3) and (6), we find that the magnitude of the penalty of 8 am and 9 am classes relative to 1 pm classes for male students are almost double the estimated effect on female students. In addition, male students have a larger benefit from late afternoon classes relative to female students.

\section{< INSERT TABLE 5 HERE >}

To address concerns about any remaining unobserved student characteristics, such as some students do better than others in morning classes, we also estimate regressions with student fixed-effects. The results of these regressions are reported in Table 6. While all regressions in Table 6 control for student fixed-effects, the columns follow the same pattern as the earlier tables: column (1) reports on a specification with department fixed effects; the regression in column (2) includes faculty fixed effects; and the column (3) regression includes both department and faculty fixed effects. The grade penalty for taking 8 am classes increases relative to all of the other specifications. All the other morning times also have a deleterious effect on student grades relative to $1 \mathrm{pm}$ classes.

< <INSERT TABLE 6 HERE〉> 


\section{Conclusion}

The estimates of this paper consistently demonstrates that morning classes, especially those held at 8 am and 9 am, are bad for grades and presumably for learning. In particular, male students appear to face particularly large effects on grades based on the time of day when their courses meet. The results of this study confirm the findings of previous studies at the college level at both a large public school and a military academy. While limited resources may push for additional early classes to make the most of existing classroom space, there appears to be a modest trade-off in terms of lower student achievement. Policy makers should consider alternatives to morning classes such as late afternoon or evening classes. While athletic practice and other co-curricular activities in the evening make it harder to have class meetings in the evening, there appear to be benefits to student learning. 


\section{References}

Achen, Alexandra C. and Paul N. Courant. (2009). What are grades made of? Journal of Economic Perspectives 23(3), 77-92.

Ahrberg, K., Martin Dresler, Sophie Niedermaier, A Steiger, and Lisa Genzel. (2012). The interaction between sleep quality and academic performance. Journal of Psychiatric Research 46, 1618-1622.

Carrell, Scott E., Teny Maghakian, and James E. West. (2011). A's from Zzzz's? The causal effect of school start time on the academic achievement of adolescents. American Economic Journal: Economic Policy 3(3), 62-81.

Cortes, Kalena E., Jesse Bricker, and Chris Rohlfs. (2010). The role of specific subjects in education production functions: Evidence from morning classes in Chicago public high schools. The BE Journal of Economic Analysis \& Policy 12(1).

Diette, Timothy M. and Manu Raghav. (2015). Class size matters: Heterogeneous effects of larger classes on college student learning. Eastern Economic Journal 41(2), 273-283.

Dills, Angela K. and Hernández-Julián, Rey. (2008). Course scheduling and academic performance. Economics of Education Review 27(6), 646-654.

Edwards, Finley. (2012). Early to rise? The effect of daily start times on academic performance. Economics of Education Review 31(6): 970-983.

Jacob, Brian A. and Jonah E. Rockoff. (2011). Organizing schools to improve student achievement: start times, grade configurations, and teacher assignments, Brookings Institution, Hamilton Project.

Perkinson-Gloor, Nadine, Sakari Lemola, and Alexander Grob. (2013). Sleep duration, positive attitude toward life, and academic achievement: The role of daytime tiredness, behavioral persistence, and school start times. Journal of Adolescence 36(2), 311-318.

Skinner, Nicholas F. (1985), University grades and time of day of instruction', Bulletin of the Psychonomic Society 23(1), 67-67.

Wolfson, Amy R. and Mary A. Carskadon. (2003). Understanding adolescents' sleep patterns and school performance: a critical appraisal. Sleep Medicine Reviews 7(6), 491-506. 
Table 1: Summary Statistics of Quantitative Variables

\begin{tabular}{ccccccc}
\hline Variable & Mean & $\begin{array}{c}\text { Standard } \\
\text { Deviation }\end{array}$ & $\begin{array}{c}\mathbf{2 5}^{\text {th }} \\
\text { Percentile }\end{array}$ & $\begin{array}{c}\mathbf{5 0}^{\text {th }} \\
\text { Percentile }\end{array}$ & $\begin{array}{c}\mathbf{7 5}^{\text {th }} \\
\text { Percentile }^{\text {Observations }}\end{array}$ & Obser \\
\hline Grade Point & 3.22 & 0.75 & 3 & 3.33 & 3.67 & 115,610 \\
SAT Math & 676 & 57.9 & 640 & 680 & 710 & 115,610 \\
SAT Verbal & 674 & 62.6 & 630 & 680 & 710 & 115,610 \\
Class Size & 21.2 & 11 & 15 & 20 & 25 & 115,610 \\
\hline
\end{tabular}


Table 2: Frequency Distribution of Categorical Variables

\begin{tabular}{|c|c|c|c|c|}
\hline Variable & Category & & Frequency & Percent \\
\hline \multicolumn{5}{|l|}{ Sex } \\
\hline & Female & & 53,619 & 46.38 \\
\hline & Male & & 61,991 & 53.62 \\
\hline & & Total & 115,610 & 100 \\
\hline \multicolumn{5}{|c|}{ Academic Standing } \\
\hline & First Year & & 32,006 & 27.68 \\
\hline & Sophomore & & 31,811 & 27.52 \\
\hline & Junior & & 26,923 & 23.29 \\
\hline & Senior & & 24,870 & 21.51 \\
\hline & & Total & 115,610 & 100 \\
\hline \multicolumn{5}{|c|}{ Course Level } \\
\hline & 100 & & 54,142 & 46.83 \\
\hline & 200 & & 35,896 & 31.05 \\
\hline & 300 & & 25,572 & 22.12 \\
\hline & & Total & 115,610 & 100 \\
\hline \multicolumn{5}{|c|}{ Class Time } \\
\hline & $8 \mathrm{am}$ & & 7,759 & 6.71 \\
\hline & $9 \mathrm{am}$ & & 15,043 & 13.01 \\
\hline & $10 \mathrm{am}$ & & 27,033 & 23.38 \\
\hline & $11 \mathrm{am}$ & & 12,146 & 10.51 \\
\hline & $12 \mathrm{pm}$ & & 13,082 & 11.32 \\
\hline & $1 \mathrm{pm}$ & & 20,945 & 18.12 \\
\hline & $2 \mathrm{pm}$ & & 10,806 & 9.35 \\
\hline & $3 \mathrm{pm}$ & & 7,176 & 6.21 \\
\hline & $4 \mathrm{pm}$ & & 520 & 0.45 \\
\hline & $5 \mathrm{pm}$ & & 1,100 & 0.95 \\
\hline & & Total & 115,610 & 100 \\
\hline
\end{tabular}


Table 3: Linear Regressions with All Courses and All Students

\begin{tabular}{|c|c|c|c|}
\hline & (1) & $(2)$ & (3) \\
\hline \multirow[t]{2}{*}{$8 \mathrm{am}$} & $-0.108 * * *$ & $-0.067 * * *$ & $-0.061 * * *$ \\
\hline & $(0.010)$ & $(0.011)$ & $(0.012)$ \\
\hline \multirow[t]{2}{*}{$9 \mathrm{am}$} & $-0.076 * * *$ & $-0.056 * * *$ & $-0.053 * * *$ \\
\hline & $(0.008)$ & $(0.009)$ & $(0.009)$ \\
\hline \multirow[t]{2}{*}{$10 \mathrm{am}$} & $-0.059 * * *$ & $-0.043 * * *$ & $-0.042 * * *$ \\
\hline & $(0.006)$ & $(0.007)$ & $(0.007)$ \\
\hline \multirow[t]{2}{*}{$11 \mathrm{am}$} & $-0.079 * * *$ & $-0.038 * * *$ & $-0.036 * * *$ \\
\hline & $(0.008)$ & $(0.009)$ & $(0.009)$ \\
\hline \multirow[t]{2}{*}{ Noon } & $-0.046 * * *$ & $-0.044 * * *$ & $-0.036 * * *$ \\
\hline & $(0.008)$ & (0.009) & $(0.009)$ \\
\hline \multirow[t]{2}{*}{$2 \mathrm{pm}$} & $0.024 * * *$ & $0.032 * * *$ & $0.031 * * *$ \\
\hline & $(0.008)$ & $(0.009)$ & $(0.009)$ \\
\hline \multirow[t]{2}{*}{$3 \mathrm{pm}$} & $0.031 * * *$ & 0.016 & 0.016 \\
\hline & $(0.009)$ & $(0.010)$ & $(0.010)$ \\
\hline \multirow[t]{2}{*}{$4 \mathrm{pm}$} & $0.134 * * *$ & $0.182 * * *$ & $0.175 * * *$ \\
\hline & $(0.029)$ & $(0.030)$ & $(0.030)$ \\
\hline \multirow[t]{2}{*}{$5 \mathrm{pm}$} & $0.523 * * *$ & $0.380 * * *$ & $0.381 * * *$ \\
\hline & $(0.018)$ & $(0.025)$ & $(0.025)$ \\
\hline \multirow{2}{*}{ Male } & $-0.164 * * *$ & $-0.160 * * *$ & $-0.161 * * *$ \\
\hline & $(0.004)$ & $(0.004)$ & $(0.004)$ \\
\hline \multirow[t]{2}{*}{ SAT Math } & $0.002 * * *$ & $0.002 * * *$ & $0.002 * * *$ \\
\hline & $(0.000)$ & $(0.000)$ & $(0.000)$ \\
\hline \multirow[t]{2}{*}{ SAT Verbal } & $0.001 * * *$ & $0.001 * * *$ & $0.001 * * *$ \\
\hline & $(0.000)$ & $(0.000)$ & $(0.000)$ \\
\hline \multirow[t]{2}{*}{ Class Size } & $-0.004 * * *$ & $-0.005 * * *$ & $-0.004 * * *$ \\
\hline & $(0.000)$ & $(0.000)$ & $(0.000)$ \\
\hline \multirow[t]{2}{*}{ Second Semester } & $0.014 * * *$ & $0.009 *$ & 0.006 \\
\hline & $(0.005)$ & $(0.005)$ & $(0.005)$ \\
\hline \multirow[t]{2}{*}{ Short Semester } & $0.154 * * *$ & $0.132 * * *$ & $0.130 * * *$ \\
\hline & $(0.007)$ & $(0.007)$ & $(0.007)$ \\
\hline \multirow[t]{2}{*}{ Sophomore } & $0.079 * * *$ & $0.071 * * *$ & $0.068 * * *$ \\
\hline & $(0.006)$ & $(0.006)$ & $(0.006)$ \\
\hline \multirow[t]{2}{*}{ Junior } & $0.105 * * *$ & $0.092 * * *$ & $0.086 * * *$ \\
\hline & $(0.007)$ & $(0.007)$ & $(0.007)$ \\
\hline \multirow[t]{2}{*}{ Senior } & $0.120 * * *$ & $0.095 * * *$ & $0.086^{* * *}$ \\
\hline & $(0.007)$ & $(0.007)$ & $(0.008)$ \\
\hline \multirow[t]{2}{*}{ 200-Level Course } & $0.049 * * *$ & $0.077 * * *$ & $0.076 * * *$ \\
\hline & $(0.006)$ & $(0.007)$ & $(0.007)$ \\
\hline \multirow[t]{2}{*}{ 300-Level Course } & $0.147 * * *$ & $0.197 * * *$ & $0.201 * * *$ \\
\hline & $(0.007)$ & $(0.008)$ & $(0.008)$ \\
\hline \multirow[t]{2}{*}{ Constant } & $1.072 * * *$ & $1.081 * * *$ & $1.225^{* * *}$ \\
\hline & $(0.034)$ & $(0.042)$ & $(0.060)$ \\
\hline Department Fixed Effects & Yes & No & Yes \\
\hline Faculty Fixed Effects & No & Yes & Yes \\
\hline Year Fixed Effects & Yes & Yes & Yes \\
\hline Observations & 115,610 & 115,610 & 115,610 \\
\hline R-squared & 0.117 & 0.163 & 0.166 \\
\hline
\end{tabular}

Notes: Grade point is the dependent variable. The baseline category for time is $1 \mathrm{pm}$. OLS standard errors are reported in parentheses for the first regression. Robust standard errors in parentheses for all other regressions. $* * * p<0.01, * * \mathrm{p}<0.05$, * $\mathrm{p}<0.1$. 
Table 4: Regressions with Courses that have Multiple Sections where Students are Randomly Assigned to Different Sections

\begin{tabular}{|c|c|c|c|}
\hline & (1) & (2) & (3) \\
\hline $8 \mathrm{am}$ & $\begin{array}{c}-0.108 * * * \\
(0.014)\end{array}$ & $\begin{array}{c}-0.085 * * * \\
(0.015)\end{array}$ & $\begin{array}{c}-0.084 * * * \\
(0.015)\end{array}$ \\
\hline 9 am & $\begin{array}{c}-0.057 * * * \\
(0.013)\end{array}$ & $\begin{array}{c}-0.053 * * * \\
(0.014)\end{array}$ & $\begin{array}{c}-0.047 * * * \\
(0.014)\end{array}$ \\
\hline $10 \mathrm{am}$ & $\begin{array}{c}-0.044 * * * \\
(0.010)\end{array}$ & $\begin{array}{c}-0.036 * * * \\
(0.011)\end{array}$ & $\begin{array}{c}-0.034 * * * \\
(0.011)\end{array}$ \\
\hline $11 \mathrm{am}$ & $\begin{array}{c}-0.054 * * * \\
(0.012)\end{array}$ & $\begin{array}{l}-0.019 \\
(0.013)\end{array}$ & $\begin{array}{l}-0.019 \\
(0.014)\end{array}$ \\
\hline Noon & $\begin{array}{c}-0.039 * * * \\
(0.012)\end{array}$ & $\begin{array}{c}-0.035 * * * \\
(0.013)\end{array}$ & $\begin{array}{c}-0.030 * * \\
(0.013)\end{array}$ \\
\hline $2 \mathrm{pm}$ & $\begin{array}{c}0.047 * * * \\
(0.012)\end{array}$ & $\begin{array}{c}0.046 * * * \\
(0.013)\end{array}$ & $\begin{array}{c}0.036 * * * \\
(0.013)\end{array}$ \\
\hline $3 \mathrm{pm}$ & $\begin{array}{c}0.032 * * \\
(0.014)\end{array}$ & $\begin{array}{c}0.004 \\
(0.015)\end{array}$ & $\begin{array}{c}0.005 \\
(0.015)\end{array}$ \\
\hline $4 \mathrm{pm}$ & $\begin{array}{c}0.087 * * \\
(0.042)\end{array}$ & $\begin{array}{c}0.213 * * * \\
(0.044)\end{array}$ & $\begin{array}{c}0.203 * * * \\
(0.044)\end{array}$ \\
\hline $5 \mathrm{pm}$ & $\begin{array}{c}0.576 * * * \\
(0.028)\end{array}$ & $\begin{array}{c}0.432 * * * \\
(0.047)\end{array}$ & $\begin{array}{c}0.437 * * * \\
(0.047)\end{array}$ \\
\hline Male & $\begin{array}{c}-0.162 * * * \\
(0.006)\end{array}$ & $\begin{array}{c}-0.158 * * * \\
(0.006)\end{array}$ & $\begin{array}{c}-0.157 * * * \\
(0.006)\end{array}$ \\
\hline SAT Math & $\begin{array}{c}0.002 * * * \\
(0.000)\end{array}$ & $\begin{array}{c}0.002 * * * \\
(0.000)\end{array}$ & $\begin{array}{c}0.002 * * * \\
(0.000)\end{array}$ \\
\hline SAT Verbal & $\begin{array}{c}0.001 * * * \\
(0.000)\end{array}$ & $\begin{array}{c}0.001 * * * \\
(0.000)\end{array}$ & $\begin{array}{c}0.001 * * * \\
(0.000)\end{array}$ \\
\hline Class Size & $\begin{array}{c}-0.005^{* * * *} \\
(0.001)\end{array}$ & $\begin{array}{c}-0.007 * * * \\
(0.001)\end{array}$ & $\begin{array}{c}-0.006 * * * \\
(0.001)\end{array}$ \\
\hline Second Semester & $\begin{array}{c}0.007 \\
(0.006)\end{array}$ & $\begin{array}{c}0.002 \\
(0.007)\end{array}$ & $\begin{array}{l}-0.001 \\
(0.007)\end{array}$ \\
\hline Short Semester & $\begin{array}{c}0.105 * * * \\
(0.015)\end{array}$ & $\begin{array}{c}0.092 * * * \\
(0.017)\end{array}$ & $\begin{array}{c}0.088 * * * \\
(0.017)\end{array}$ \\
\hline Sophomore & $\begin{array}{c}0.051 * * * \\
(0.009)\end{array}$ & $\begin{array}{c}0.039 * * * \\
(0.009)\end{array}$ & $\begin{array}{c}0.041 * * * \\
(0.009)\end{array}$ \\
\hline Junior & $\begin{array}{c}0.074 * * * \\
(0.011)\end{array}$ & $\begin{array}{c}0.059 * * * \\
(0.011)\end{array}$ & $\begin{array}{c}0.056 * * * \\
(0.011)\end{array}$ \\
\hline Senior & $\begin{array}{c}0.058 * * * \\
(0.012)\end{array}$ & $\begin{array}{c}0.041^{* * *} * \\
(0.012)\end{array}$ & $\begin{array}{c}0.037 * * * \\
(0.012)\end{array}$ \\
\hline 200-Level Course & $\begin{array}{l}0.021^{*} \\
(0.011)\end{array}$ & $\begin{array}{c}0.069 * * * \\
(0.014)\end{array}$ & $\begin{array}{c}0.075^{* * * *} \\
(0.014)\end{array}$ \\
\hline 300-Level Course & $\begin{array}{c}0.101 * * * \\
(0.013)\end{array}$ & $\begin{array}{c}0.227 * * * \\
(0.017)\end{array}$ & $\begin{array}{c}0.234 * * * \\
(0.017)\end{array}$ \\
\hline Constant & $\begin{array}{c}0.728 * * * \\
(0.052)\end{array}$ & $\begin{array}{c}0.840 * * * \\
(0.072)\end{array}$ & $\begin{array}{c}0.794 * * * \\
(0.072)\end{array}$ \\
\hline Department Fixed Effects & Yes & No & Yes \\
\hline Faculty Fixed Effects & No & Yes & Yes \\
\hline Year Fixed Effects & Yes & Yes & Yes \\
\hline $\begin{array}{l}\text { Observations } \\
\text { R-squared }\end{array}$ & $\begin{array}{c}58,089 \\
0.108\end{array}$ & $\begin{array}{c}58,089 \\
0.158\end{array}$ & $\begin{array}{c}58,089 \\
0.160\end{array}$ \\
\hline
\end{tabular}

Notes: Grade point is the dependent variable. OLS standard errors are reported in parentheses for the first regression. Robust standard errors in parentheses for all other regressions. The baseline category for time is $1 \mathrm{pm} . * * * \mathrm{p}<0.01, * * \mathrm{p}<0.05, * \mathrm{p}<0.1$. 
Table 5: Linear Regressions for Male and Female Students

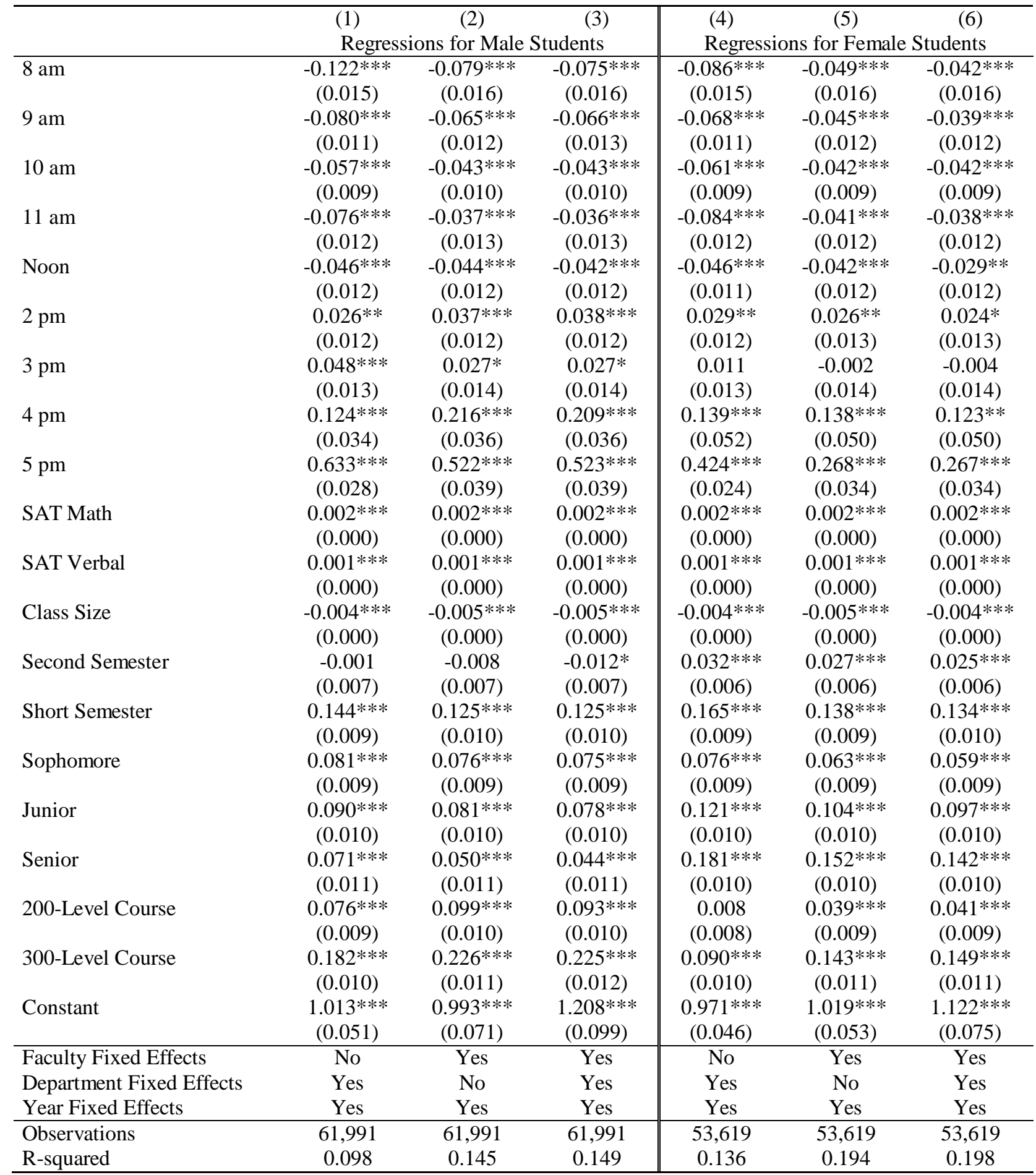

Notes: Grade point is the dependent variable. Robust standard errors in parentheses. ${ }^{* * *} \mathrm{p}<0.01,{ }^{* *} \mathrm{p}<0.05,{ }^{*} \mathrm{p}<0.1$.

The baseline category for time is $1 \mathrm{pm}$. 
Table 6: Linear Regressions with Student Fixed-Effects

\begin{tabular}{|c|c|c|c|}
\hline & (1) & (2) & (3) \\
\hline \multirow[t]{2}{*}{$8 \mathrm{am}$} & $-0.128 * * *$ & $-0.083 * * *$ & $-0.077 * * *$ \\
\hline & $(0.009)$ & $(0.009)$ & $(0.010)$ \\
\hline \multirow[t]{2}{*}{$9 \mathrm{am}$} & $-0.086 * * *$ & $-0.060 * * *$ & $-0.054 * * *$ \\
\hline & $(0.007)$ & $(0.007)$ & $(0.007)$ \\
\hline \multirow[t]{2}{*}{$10 \mathrm{am}$} & $-0.069 * * *$ & $-0.049 * * *$ & $-0.048 * * *$ \\
\hline & $(0.005)$ & $(0.006)$ & $(0.006)$ \\
\hline \multirow[t]{2}{*}{$11 \mathrm{am}$} & $-0.085 * * *$ & $-0.032 * * *$ & $-0.032 * * *$ \\
\hline & $(0.007)$ & $(0.007)$ & $(0.007)$ \\
\hline \multirow[t]{2}{*}{ Noon } & $-0.047 * * *$ & $-0.048 * * *$ & $-0.036 * * *$ \\
\hline & $(0.007)$ & $(0.007)$ & $(0.007)$ \\
\hline \multirow[t]{2}{*}{$2 \mathrm{pm}$} & $0.031 * * *$ & $0.036 * * *$ & $0.038 * * *$ \\
\hline & $(0.007)$ & $(0.007)$ & $(0.007)$ \\
\hline \multirow[t]{2}{*}{$3 \mathrm{pm}$} & $0.041 * * *$ & $0.028 * * *$ & $0.029 * * *$ \\
\hline & $(0.008)$ & $(0.008)$ & $(0.008)$ \\
\hline \multirow[t]{2}{*}{$4 \mathrm{pm}$} & $0.182 * * *$ & $0.202 * * *$ & $0.188 * * *$ \\
\hline & $(0.029)$ & $(0.030)$ & $(0.030)$ \\
\hline \multirow[t]{2}{*}{$5 \mathrm{pm}$} & $0.410 * * *$ & $0.284 * * *$ & $0.283 * * *$ \\
\hline & $(0.021)$ & $(0.027)$ & $(0.027)$ \\
\hline \multirow[t]{2}{*}{ Class Size } & $-0.003 * * *$ & $-0.005 * * *$ & $-0.004 * * *$ \\
\hline & $(0.000)$ & $(0.000)$ & $(0.000)$ \\
\hline \multirow[t]{2}{*}{ Second Semester } & $0.008 * *$ & 0.001 & -0.002 \\
\hline & $(0.004)$ & $(0.004)$ & $(0.004)$ \\
\hline \multirow[t]{2}{*}{ Short Semester } & $0.178 * * *$ & $0.154 * * *$ & $0.154 * * *$ \\
\hline & $(0.006)$ & $(0.006)$ & $(0.006)$ \\
\hline \multirow[t]{2}{*}{ 200-Level Course } & $0.014 * * *$ & $0.048 * * *$ & $0.049 * * *$ \\
\hline & $(0.005)$ & $(0.006)$ & $(0.006)$ \\
\hline \multirow[t]{2}{*}{ 300-Level Course } & $0.076 * * *$ & $0.126 * * *$ & $0.127 * * *$ \\
\hline & $(0.006)$ & $(0.007)$ & $(0.007)$ \\
\hline \multirow[t]{2}{*}{ Constant } & $3.540 * * *$ & $3.609 * * *$ & $3.571 * * *$ \\
\hline & $(0.139)$ & $(0.141)$ & $(0.143)$ \\
\hline Faculty Fixed Effects & No & Yes & Yes \\
\hline Department Fixed Effects & Yes & No & Yes \\
\hline Year Fixed Effects & Yes & Yes & Yes \\
\hline Student Fixed Effects & Yes & Yes & Yes \\
\hline Observations & 115,610 & 115,610 & 115,610 \\
\hline R-squared & 0.427 & 0.469 & 0.472 \\
\hline
\end{tabular}

Notes: Grade point is the dependent variable. Robust standard errors in parentheses. $* * * \mathrm{p}<0.01$, ** $\mathrm{p}<0.05$, $* \mathrm{p}<0.1$. No studentlevel characteristics are included in the regression specification as it includes student fixed-effects. The baseline category for time is $1 \mathrm{pm}$. 